\title{
Nutritional status of coriander under fertigation depths and pulse and continuous drip irrigation
}

\author{
Sirleide M. de Menezes ${ }^{1}$, Gerônimo F. da Silva ${ }^{1}$, Valentin R. Ó. Zamora ${ }^{1}$, Manassés M. da Silva ${ }^{1}$, \\ Anna C. R. A. da Silva ${ }^{1} \&$ Ênio F. de F. e Silva ${ }^{1}$
} ${ }^{1}$ Universidade Federal Rural de Pernambuco/Departamento de Engenharia Agrícola/Programa de Pós-Graduação em Engenharia Agrícola, Recife,
PE, Brasil. E-mail: sirleidemeneses@hotmail.com (Corresponding author) - ORCID: 0000-0003-1225-5572; geronimo.silva@ufrpe.br - ORCID:
0000-0002-3348-7252; vorcon2871@gmail.com - ORCID: 0000-0001-6010-5806; manasses.ufrpe@gmail.com - ORCID: 0000-0002-3316-8024;
cecilia.ribeiro.414@gmail.com - ORCID: 0000-0003-0856-0478; enio.fsilva@ufrpe.br - ORCID: 0000-0002-8652-503X

\begin{abstract}
The objective of this study was to evaluate the nutritional status of coriander cultivar Verdão under fertigation depths and pulse and continuous drip irrigation. The experiment was conducted in a protected environment at the Universidade Federal Rural de Pernambuco, Recife, PE, Brazil ( $8^{\circ} 1^{\prime}$ 6.50" S, $34^{\circ} 56^{\prime} 46^{\prime \prime} \mathrm{W}$ and altitude of $6.5 \mathrm{~m}$ ), in the randomized block design in $2 \times 5$ factorial scheme, with three repetitions. Treatments consisted of five irrigation depths $(40,60,80,100$ and $120 \%$ of crop evapotranspiration - ETc) and two types of fertigation application (pulse and continuous). At 27 days after sowing, the aerial part of 48 plants per plot was collected for subsequent quantification of nitrogen, phosphorus, potassium, calcium, magnesium, sulfur, iron, manganese, copper and zinc concentrations. Pulse fertigation combined with ETc replacement depths below 100\% promoted higher leaf concentrations of phosphorus, sulfur, iron and manganese. Continuous fertigation combined with $100 \%$ ETc depth induced sulfur deficiency in the crop and, combined with $40 \%$ ETc depth, promoted the highest calcium concentration. Regardless of the type of application, ETc replacement depths from 82.7 and $40 \%$ provide adequate leaf concentrations of nitrogen and magnesium, respectively. Regardless of the applied depth, pulse fertigation reduced the leaf concentrations of magnesium.
\end{abstract}

Key words: Coriandrum sativum L., pulse irrigation, mineral nutrition

\section{Estado nutricional do coentro sob lâminas de fertirrigação e gotejamento por pulso e contínuo}

\begin{abstract}
RESUMO: Objetivou-se avaliar o estado nutricional do coentro cultivar Verdão sob lâminas de fertirrigação e gotejamento por pulso e contínuo. O experimento foi conduzido em ambiente protegido da Universidade Federal Rural de Pernambuco, Recife, PE ( $8^{\circ} 1^{\prime}$ 6,50" S, 34 $4^{\circ} 56^{\prime} 46^{\prime \prime} \mathrm{O}$ e altitude de $6,5 \mathrm{~m}$ ), no delineamento em blocos casualizados em esquema fatorial 2 x 5, com três repetições. Os tratamentos foram constituídos por cinco lâminas de irrigação (40, 60, 80, 100 e 120\% da evapotranspiração da cultura - ETc) e dois tipos de aplicação da fertirrigação (por pulso e contínua). Aos 27 dias após a semeadura coletou-se a parte aérea de 48 plantas por parcela para posterior quantificação dos teores de nitrogênio, fósforo, potássio, cálcio, magnésio, enxofre, ferro, manganês, cobre e zinco. A fertirrigação por pulso combinada com lâminas de reposição da ETc inferiores a 100\% proporcionaram maiores teores foliares de fósforo, enxofre, ferro e manganês. A fertirrigação contínua com a lâmina de $100 \%$ da ETc induziu deficiência de enxofre na cultura e, combinada com a lâmina de $40 \%$, proporcionou o maior teor de cálcio. Independentemente do tipo de aplicação, lâminas de reposição da ETc a partir de 82,7 e de $40 \%$, proporcionam teores foliares, respectivamente, de nitrogênio e de magnésio considerados adequados. Independente da lâmina aplicada, a fertirrigação por pulso reduziu os teores foliares de magnésio.
\end{abstract}

Palavras-chave: Coriandrum sativum L., irrigação por pulsos, nutrição mineral 


\section{INTRODUCTION}

The use of techniques and tools that promote the rationalization of inputs and increments in agricultural production is necessary for the development of an intensive and sustainable agriculture. Among the new techniques developed to support irrigation management, there is pulse irrigation, a concept with recent studies that has the potential to maximize the use of water and fertilizers.

This technique consists in applying the daily irrigation depth in small portions in a series of on-off irrigation cycles, and each event contains an irrigation phase and a resting phase (Almeida et al., 2015; García-Prats \& Guillem-Picó, 2016). Pulse irrigation has shown positive and promising results such as increments in product yield and quality, water saving and improvement in nutrient absorption (Assouline et al., 2006; Elnesr et al., 2015).

The determination of crop evapotranspiration (ETc) is extremely important for the correct planning, designing and management of any irrigation system. This variable depends on meteorological, crop and soil elements and can be measured directly (lysimeters) or indirectly, by combined equations (Oliveira et al., 2015). The use of pulse irrigation associated with the real water requirement of the crop can promote reduction in production costs and increments in yield.

Coriander (Coriandrum sativum L.) is a leafy vegetable widely used in the world, which is associated with its versatility in cooking, pharmaceutical industries, food industries and as an aromatic plant (Bhat et al., 2014). Its cultivation is mainly carried out by small and medium-sized producers, but it has a relevant socioeconomic importance (Grangeiro et al., 2011).

Data on the cultivation of coriander under pulse drip fertigation are scarce, and their relationship with the nutritional status of the crop is relevant to establish fertilization management strategies aimed at increasing yield and rationalization of inputs and water resources, generating more information for farmers. Thus, the objective of this study was to evaluate the nutritional status of coriander under pulse and continuous drip fertigation depths.

\section{Material ANd Methods}

The experiment was conducted from August to September 2017 , in a protected environment in the Department of Agronomy - DEPA of the Universidade Federal Rural de Pernambuco, UFRPE, Dois Irmãos Campus, in Recife, PE, Brazil ( $8^{\circ} 1^{\prime} 6.50^{\prime \prime} \mathrm{S}, 34^{\circ} 56^{\prime} 46^{\prime \prime} \mathrm{W}$ and altitude of $6.5 \mathrm{~m}$ ). According to Köppen's classification, the climate of the region is of As', hot and humid (Alvares et al., 2014).

The experimental plots were installed in a gable-roof greenhouse with an area of $162 \mathrm{~m}^{2}$. Inside the greenhouse, the average maximum and minimum temperatures were 34.35 and $25.66^{\circ} \mathrm{C}$, respectively, and the average values of maximum and minimum air relative humidity were 92.22 and 55.90\%, respectively. Both were monitored using a DHT11 sensor controlled by an Arduino board microcontroller.

The experimental units built inside the greenhouse were composed of 30 masonry beds with dimensions of $1.0 \mathrm{~m}^{2}$ (5.0 x $0.20 \mathrm{~m}$ ) and depth of $0.20 \mathrm{~m}$, each of which had drainage system and internal walls lined with a polyethylene plastic film for waterproofing purposes.

The soil used to fill the beds was a Spodosol (sandy texture), with sand, silt and clay contents of 90.4, 3.2 and $6.4 \%$, respectively. Bulk and particle densities were 1.5 and $2.5 \mathrm{~kg} \mathrm{dm}^{-3}$, respectively, obtained by the volumetric ring method. The soil water storage limits were $0.10 \mathrm{~m}^{3} \mathrm{~m}^{-3}$ (field capacity), obtained by the tension table method and $0.09 \mathrm{~m}^{3} \mathrm{~m}^{-3}$ (permanent wilting point), obtained by the Richards's pressure plate apparatus method.

Chemical analysis of the soil performed before filling the beds showed the following results: $\mathrm{pH}$ (water 1:2.5) = 5.1; $\mathrm{Ca}^{2+}=0.30 \mathrm{cmol} \mathrm{dm}^{-3} ; \mathrm{Mg}^{2+}=0.22 \mathrm{cmol} \mathrm{dm}_{c}^{-3} ; \mathrm{Al}^{3+}=0.2 \mathrm{cmol} \mathrm{dm}^{-3}$; $\mathrm{Na}^{+}=0.01 \mathrm{cmol}_{\mathrm{c}} \mathrm{dm}^{-3} ; \mathrm{K}^{+}=0.01 \mathrm{cmol}_{\mathrm{c}} \mathrm{dm}^{-3} ; \mathrm{P}=2.0 \mathrm{mg} \mathrm{dm}{ }^{-3} ;$ $\mathrm{OM}=9.69 \mathrm{~g} \mathrm{~kg}^{-1} ;\left(\mathrm{H}^{+}+\mathrm{Al}^{+}\right)=4.68 \mathrm{cmol}_{\mathrm{c}} \mathrm{dm}^{-3}$. After obtaining these results and verifying the low cation exchange capacity of the soil, it was decided to use a standard nutrient solution, which makes the cultivation system semi-hydroponic.

The experimental design was randomized blocks in a $2 \times 5$ factorial scheme, with the first factor represented by two types of fertigation application (pulse and continuous) and the second factor represented by five irrigation depths (40, $60,80,100$ and $120 \%$ of crop evapotranspiration - ETc), with three repetitions, constituting 10 treatments and totaling 30 experimental plots.

For the type of application of pulse fertigation, the total depth defined according to each ETc level applied daily was divided into six irrigation pulses with an interval of $60 \mathrm{~min}$ between applications. ETc was obtained directly based on the mean of the water balance of four drainage lysimeters with a capacity of $5.0 \mathrm{~L}$, cultivated with coriander and installed inside the greenhouse.

The drip irrigation system used was composed of drip tapes (ND $16 \mathrm{~mm}$ ) with emitters spaced by $0.30 \mathrm{~m}$ and nominal flow rate of $0.60 \mathrm{~L} \mathrm{~h}^{-1}$, with application intensity of $13.2 \mathrm{~mm} \mathrm{~h}^{-1}$, which supplied the experimental plots individually. The irrigation system was equipped with valves, solenoid valves (Marcoval), pressure regulator (regulated at 10.0 m.w.c - Fabrimar), Arduino board microcontroller (ATMega16U2), disc filter (Irritec) and a centrifugal electric pump (0.5 HP - Ferrari).

The irrigation time of each treatment was calculated considering the gross irrigation depth, obtained by the relationship between daily ETc and application efficiency (95\%) of the irrigation system. The treatments began to be applied at 13 days after sowing (DAS), when the crop showed homogeneous establishment in the plots.

The electronic control circuit of the Arduino board was responsible for automatically controlling the division of the gross irrigation depth as well as for calculating the times of application of each pulse according to each treatment, starting daily at $9 \mathrm{~h}$.

In order to correct soil acidity and neutralize exchangeable $\mathrm{Al}$, liming with calcitic limestone was performed 60 days before planting, applying $3.5 \mathrm{t} \mathrm{ha}^{-1}$, according to the methodology of Cavalcanti et al. (2008). Twenty seeds of coriander cultivar Verdão were sown directly in the beds spaced by $0.10 \times 0.15 \mathrm{~m}$. 
Fertilization was performed at daily frequency, by adding the nutrients in the irrigation water according to the nutrient solution indicated for the cultivation of leafy vegetables, proposed by Furlani (1998) (Table 1), prepared in public-supply water. Therefore, the daily irrigations were carried out using nutrient solution, thus becoming fertigation events.

Phosphorus was conventionally applied at planting (120 kg ha ${ }^{-1}$ of $\mathrm{P}_{2} \mathrm{O}_{5}$ ) based on soil chemical analysis, according to Cavalcanti et al. (2008). The mean values of electrical conductivity and $\mathrm{pH}$ of the nutrient solution recorded along the experiment were $2.10 \mathrm{dS} \mathrm{m}^{-1}$ and 6.23 , respectively.

The experiment lasted 34 days, during which time the plants reached the point of fresh consumption, represented by the full vegetative development and the first signs of the beginning of the reproductive stage. Until 12 DAS, corresponding to the stage of germination and establishment of the crop, irrigation was performed in all plots replacing $100 \%$ of the ETc.

At the end of the cycle, the total consumption was equal to $42.88,64.32,85.76,107.2$ and $128.64 \mathrm{~mm}$ for the fertigation depths corresponding to $40,60,80,100$ and $120 \%$ of ETc, respectively. To determine the nutritional status of coriander cv. Verdão at 27 DAS, a period represented by full vegetative development, 48 plants were randomly collected in each experimental plot. The collected plants were dried in a forced air circulation oven $\left(65^{\circ} \mathrm{C}\right)$ until constant weight.

The nutrients $\mathrm{N}, \mathrm{P}, \mathrm{K}, \mathrm{Ca}, \mathrm{Mg}, \mathrm{S}, \mathrm{Cu}, \mathrm{Fe}, \mathrm{Mn}$ and $\mathrm{Zn}$ were extracted according to the methodology proposed by Silva (2009), and the concentrations of each nutrient were quantified according to the methodology suggested by Bezerra Neto \& Barreto (2011).

The results were analyzed by analysis of variance using the $\mathrm{F}$ test. When a significant effect was verified, polynomial regression analysis at $\mathrm{p} \leq 0.05$ was performed for the fertigation depths and Scott-Knott means comparison test at $\mathrm{p} \leq 0.05$ was applied for the types of fertigation application. The analyses were performed using the statistical software SISVAR (Ferreira, 2011).

\section{Results AND Discussion}

The analysis of variance showed significant effect $(p \leq 0.01)$ of the interaction between the types of fertigation application and depths on leaf contents of phosphorus (P), calcium (Ca), sulfur $(\mathrm{S})$, iron $(\mathrm{Fe})$ and manganese $(\mathrm{Mn})$. For the nitrogen concentration $(\mathrm{N})$, there was a significant response $(\mathrm{p} \leq 0.05)$ to the fertigation depths, while the potassium concentration $(\mathrm{K})$ was significantly influenced ( $\mathrm{p} \leq 0.01$ ) by the type of fertigation application (pulse and continuous). The concentrations of magnesium $(\mathrm{Mg})$, copper $(\mathrm{Cu})$ and zinc $(\mathrm{Zn})$ were influenced ( $\mathrm{p} \leq 0.01$ and $\mathrm{p} \leq 0.05$ ) by the two factors individually.

The effect of fertigation depths on $\mathrm{N}$ concentrations can be seen in Figure 1A. The effect of the types of fertigation application on $\mathrm{K}$ concentrations, and of both factors on $\mathrm{Mg}$ concentrations are expressed in Figures $1 \mathrm{~B}, \mathrm{C}$ and D, respectively.

Nitrogen $(\mathrm{N})$ concentrations increased linearly as a function of the applied fertigation depths (Figure 1A), with increment of $0.0795 \mathrm{~g} \mathrm{~kg}^{-1}$ for each unit increase in the fertigation depth. Such increment possibly occurred due to the higher mass flow caused by the increase in the volume of the applied fertigation depth, consequently leading to a greater amount of $\mathrm{N}$ in the soil solution and also a greater absorption of the nutrient by plants.

Oliveira et al. (2016) observed a progressive linear increase in $\mathrm{N}$ concentration in coriander plants produced in substrates fertigated with increasing concentrations of nutrient solution, in which the concentration obtained for the highest concentration evaluated (125\% ETc) was $26.7 \mathrm{~g} \mathrm{~kg}^{-1}$, which is lower than that obtained with the lowest fertigation depth (40\% ETc) of the present study.

The N concentrations obtained for the depths of 100 and $120 \%$ ETc are within the range considered as adequate for coriander crop according to Trani et al. (2014), who state that coriander plants adequately nourished with $\mathrm{N}$ must have concentrations within the range from 40 to $60 \mathrm{~g} \mathrm{~kg}^{-1}$ in the aerial part.

The potassium $(\mathrm{K})$ concentration obtained in the aerial part of coriander Verdão with the application of pulse fertigation showed increased by $17.6 \%$ compared to the continuous fertigation (Figure 1B).

These results suggest that pulse fertigation may promote the maintenance of a more constant soil moisture throughout the day, so it may possibly have contributed to a greater stability of the soil solution and, consequently, provided greater absorption of the nutrient in comparison to its absorption under continuous fertigation. On this topic, Almeida et al. (2018) state that the use of pulse drip irrigation keeps the soil moister for a longer period.

Assouline et al. (2006), studying the effects of pulse irrigation on bell pepper crop in a protected environment, observed that there was no influence of the pulses on $\mathrm{K}$ concentration and found $\mathrm{K}$ concentration in bell pepper leaves of $48.5 \mathrm{~g} \mathrm{~kg}^{-1}$. Regarding the $\mathrm{K}$ concentrations verified in the

Table 1. Amounts of fertilizers and the respective concentrations of nutrients to prepare $1000 \mathrm{~L}$ of nutrient solution for hydroponic cultivation of leafy crops

\begin{tabular}{|c|c|c|c|c|c|c|c|c|c|c|c|c|c|c|}
\hline Fertilizer & $\left(\mathrm{g} \mathrm{m}^{-3}\right)$ & $\mathrm{NH}_{4}$ & $\mathrm{NO}_{3}$ & $P$ & K & $\mathrm{Ca}$ & $\mathrm{Mg}$ & $S$ & B & Cu & $\mathrm{Fe}$ & $\mathrm{Mn}$ & Mo & $\mathrm{Zn}$ \\
\hline Cal ammo nitrate & 750.0 & 7.5 & 108.8 & & & 142.5 & & & & & & & & \\
\hline Potassium nitrate & 500.0 & & 65 & & 182.5 & & & & & & & & & \\
\hline MAP & 150.0 & 16.5 & & 39 & & & & & & & & & & \\
\hline Magnesium sulfate & 400.0 & & & & & & 40 & 52 & & & & & & \\
\hline Copper sulfate & 0.20 & & & & & & & & & 0.02 & & & & \\
\hline Zinc sulfate & 0.3 & & & & & & & & & & & & & 0.07 \\
\hline Manganese sulfate & 1.5 & & & & & & & & & & & 0.39 & & \\
\hline Boric acid & 1.8 & & & & & & & & 0.31 & & & & & \\
\hline Sodium molybdate & 0.20 & & & & & & & & & & & & 0.06 & \\
\hline Fe-EDTA- $13 \%$ Fe & 16.0 & & & & & & & & & & 2.08 & & & \\
\hline Recommendation & & 24 & 173.8 & 39 & 182.5 & 142.5 & 40 & 52 & 0.31 & 0.02 & 2.08 & 0.39 & 0.06 & 0.07 \\
\hline
\end{tabular}


A.
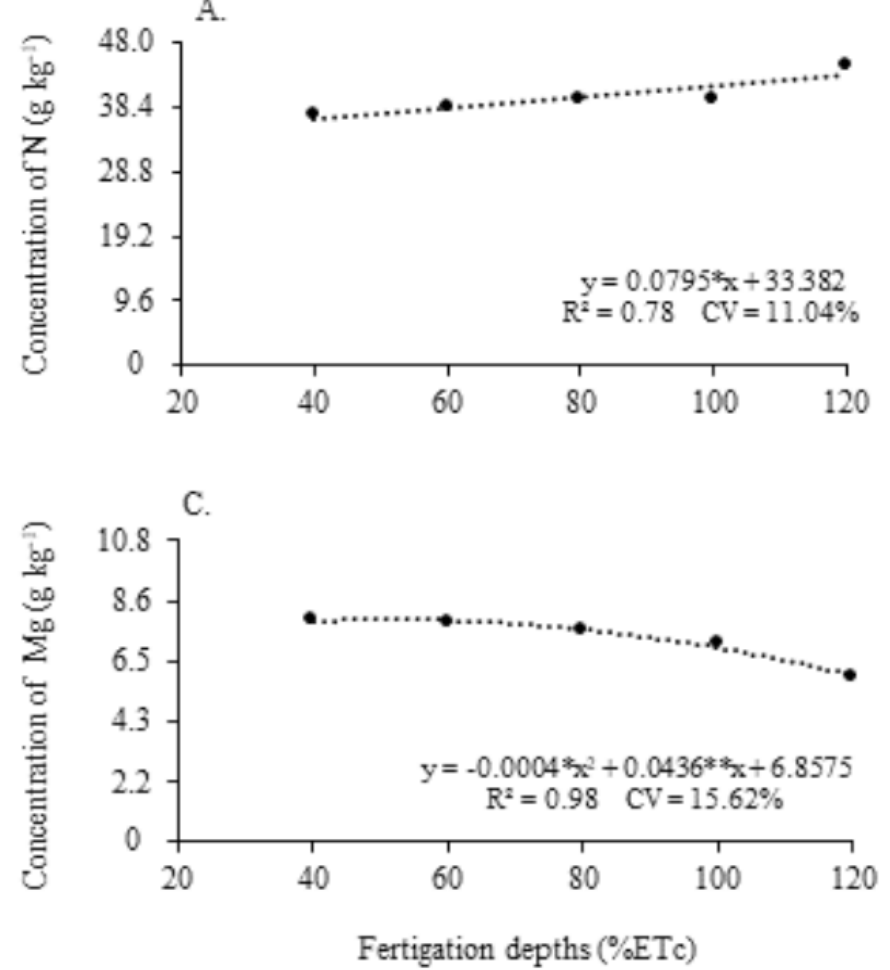

B.
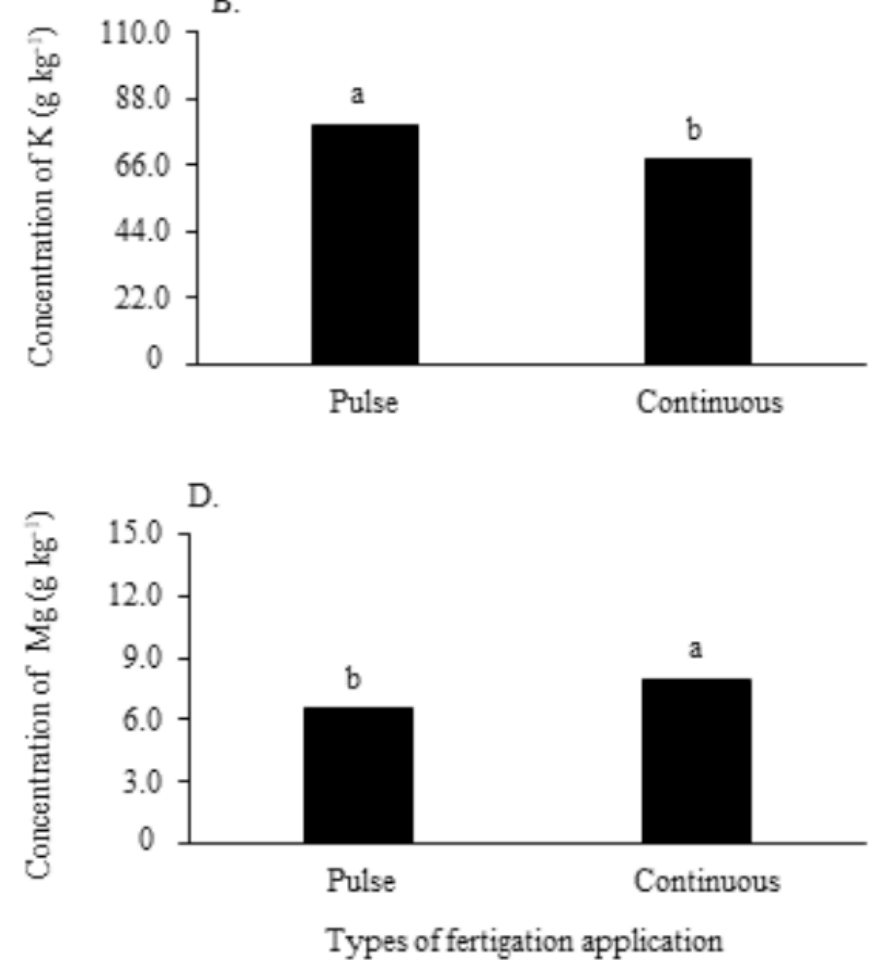

* and ${ }^{* *}$ - Significant at $\mathrm{p} \leq 0.05$ and $\mathrm{p} \leq 0.01$ by F test, respectively; Equal letters on the bars indicate non-significant differences between the types of fertigation application (pulse and continuous) by the Scott-Knott test $(\mathrm{p} \leq 0.05)$

Figure 1. Concentrations of nitrogen $(\mathrm{N})$ as a function of fertigation depths $(\mathrm{A})$, potassium $(\mathrm{K})$ as a function of the types of fertigation application (B) and of magnesium (Mg) as a function of both factors (C) and (D) in coriander cv. Verdão

present study under continuous fertigation (Figure 1B), the value was equal to $67.6 \mathrm{~g} \mathrm{~kg}^{-1}$.

Grangeiro et al. (2011) verified a K concentration of $26.7 \mathrm{~g} \mathrm{~kg}^{-1}$ in coriander cultivar Verdão and Pereira et al. (2012) found concentration of $43.5 \mathrm{~g} \mathrm{~kg}^{-1}$ in the same cultivar. By analyzing these results, it is possible to infer that the use of fertigation can promote higher $\mathrm{K}$ concentrations in the aerial part of the crop in comparison to the concentrations obtained with the use of conventional fertilization. The present study found the benefit of pulse fertigation for $\mathrm{K}$ accumulation to the detriment of continuous fertigation, regardless of the applied depth.

The magnesium $(\mathrm{Mg})$ concentrations in the coriander cv. Verdão as a function of the ETc replacement depths were described by the quadratic model (Figure 1C). The maximum $\mathrm{Mg}$ concentration estimated for the crop was 8.05 $\mathrm{g} \mathrm{kg}^{-1}$, obtained with the application of the $54.5 \%$ depth, with an increment of $1.1 \%$ in comparison to the $40 \%$ ETc depth. Corroborating these results, Becari (2015) studied the nutritional concentrations in arugula crop under different water stress conditions and observed that the $\mathrm{Mg}$ concentrations, in the highest amount of water applied to the soil $(120 \%$ field capacity) resulted in lower value of this nutrient.

Regarding the effect of the types of fertigation application, Figure 1D shows that pulse fertigation promoted $\mathrm{Mg}$ concentration of $6.58 \mathrm{~g} \mathrm{~kg}^{-1}$, while continuous fertigation led to a concentration of $7.97 \mathrm{~g} \mathrm{~kg}^{-1}$, with increment of $21.1 \%$. The relationship of antagonism between $\mathrm{K}$ and $\mathrm{Mg}$ possibly promoted lower $\mathrm{Mg}$ concentration in the leaves of coriander cv. Verdão and favored the $\mathrm{K}$ concentration for the type of application of pulse fertigation.

According to Trani et al. (2014), Mg concentrations between 3 and $5 \mathrm{~g} \mathrm{~kg}^{-1}$ are adequate for coriander. Pereira et al. (2012) obtained for this crop a concentration of $2.5 \mathrm{~g} \mathrm{~kg}^{-1}$, which is lower than that obtained in the present experiment.

The effect of the interaction between the types of fertigation application and the ETc replacement depths on phosphorus (P), calcium $(\mathrm{Ca})$ and sulfur $(\mathrm{S})$ concentrations in the aerial part of coriander cv. Verdão can be observed in Figures 2A, B and C, respectively.

For the $\mathrm{P}$ concentration, there was a quadratic effect of fertigation depths in both types of application, with reduction in its value in the application by pulses, while in the continuous application the maximum estimated $\mathrm{P}$ concentration of 5.20 $\mathrm{g} \mathrm{kg}^{-1}$ was obtained at the $76.75 \%$ ETc depth, revealing a $5.5 \%$ increase compared to the $40 \%$ ETc depth (Figure 2A).

The reduction in the irrigation depth increased the $\mathrm{P}$ content in the coriander cv. Verdão. On this aspect, Lima et al. (2016) observed that the $\mathrm{P}$ concentration in bell pepper plants increased under depths below 100\% ETc, and found maximum $\mathrm{P}$ concentration with the depth equivalent to $55 \%$ ETc. Daflon et al. (2014) obtained a P concentration of $5.59 \mathrm{~g}$ $\mathrm{kg}^{-1}$ in coriander leaves, which is consistent with those obtained in the present study. The range indicated by Trani et al. (2014) for $\mathrm{P}$ concentration in coriander leaves is between 4 and $6 \mathrm{~g} \mathrm{~kg}^{-1}$.

According to the single-effect analysis of the type of application considering each fertigation depth, there was a significant difference between pulse and continuous fertigation at the 40,60 and $120 \%$ ETc depths, revealing increments of 18.7, 7.5 and $4.1 \%$ in $\mathrm{P}$ concentrations, respectively, for pulse fertigation (Figure 2A). According to Assouline et al. (2006), the availability and absorption of $\mathrm{P}$ are favored by the high frequency of irrigation, corroborating this result.

For the Ca concentration, the single-effect analysis of the factors revealed a significant effect of the fertigation depths under 

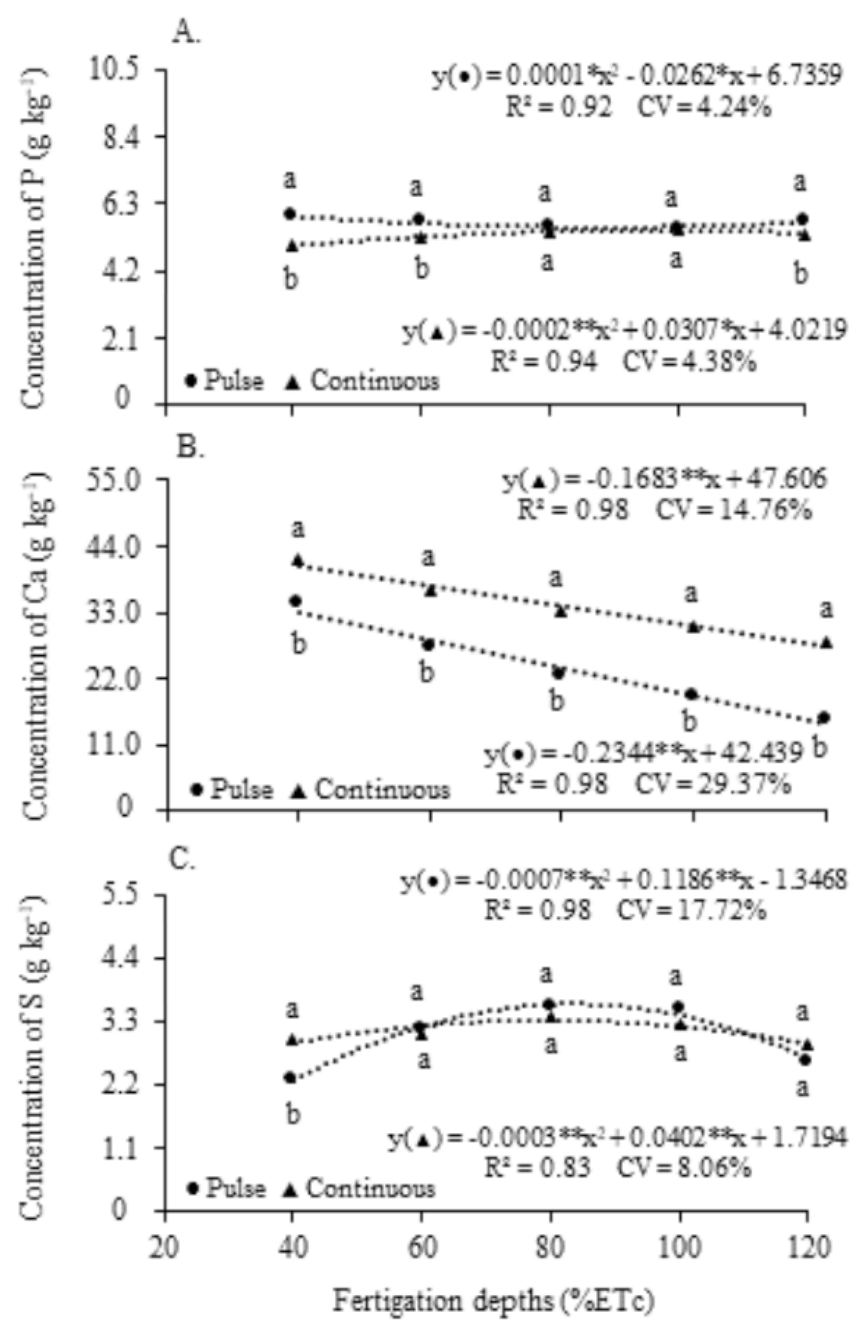

${ }^{*}$ and ${ }^{* *}$ - Significant at $\mathrm{p} \leq 0.05$ and $\mathrm{p} \leq 0.01$ by $\mathrm{F}$ test, respectively; Equal letters on the mean values indicate non-significant differences between the types of fertigation application (pulse and continuous) by the Scott-Knott test ( $\mathrm{p} \leq 0.05$ )

Figure 2. Concentrations of phosphorus (P) (A), calcium (Ca) (B) and sulfur (S) (C) in coriander cv. Verdão subjected to fertigation depths and types of application

both types of application. The Ca concentration decreased linearly as a function of the increase in fertigation depths for both types of application (Figure 2B), with the highest Ca concentration for both types of application obtained at the lowest depth studied (40\% ETc). Similarly, Albuquerque et al. (2012), studying bell pepper under water deficit, observed that the reduction in the irrigation depth favored the increase in Ca concentration in the fruits.

As observed for $\mathrm{Mg}$, the Ca concentration in the coriander cv. Verdão was possibly affected by the antagonistic relationship between $\mathrm{K}, \mathrm{Mg}$ and $\mathrm{Ca}$. The $\mathrm{K}$ is a monovalent ion that has a lower degree of hydration compared to the bivalent ions of $\mathrm{Ca}$ and $\mathrm{Mg}$, consequently having preferential absorption in comparison to $\mathrm{Ca}$ and $\mathrm{Mg}$ ions.

For continuous fertigation, the estimated Ca concentration at the $40 \%$ ETc depth was $40.87 \mathrm{~g} \mathrm{~kg}^{-1}$, with reduction of $0.1683 \mathrm{~g} \mathrm{~kg}^{-1}$ for each unit increase in the ETc replacement depth. In the type of application of pulse fertigation, the estimated concentration was equal to $33.06 \mathrm{~g} \mathrm{~kg}^{-1}$, under $40 \%$ $\mathrm{ETc}$, with reduction of $0.2344 \mathrm{~g} \mathrm{~kg}^{-1}$ for each unit increase in the ETc replacement depth (Figure 2B).

In the single-effect analysis of the type of application considering each fertigation depth, there was a significant difference in Ca concentrations between pulse and continuous fertigation at all depths applied, revealing increments of 23.6, $32.2,44.1,62,91.5 \%$ for the depths of 40, 60, 80100 and $120 \%$ ETc, respectively, in the application of continuous fertigation (Figure 2B).

The fact that continuous fertigation favored the increase of Ca concentration in coriander cv. Verdão, compared to the application of pulse fertigation, may be related to the lower $\mathrm{K}$ concentration obtained with the application of continuous fertigation and, thus, with the non-occurrence of antagonistic effects between these nutrients.

Values lower than those found in this study were obtained by Grangeiro et al. (2011), who observed Ca concentration of $22.14 \mathrm{~g} \mathrm{~kg}^{-1}$ in coriander cv. Verdão. Pereira et al. (2012) and Daflon et al. (2014) obtained concentrations of 5.7 and $9.63 \mathrm{~g} \mathrm{~kg}^{-1}$, respectively, for coriander grown under conventional fertilization. The Ca concentrations of coriander cv. Verdão obtained in this study are within the range considered as adequate by Trani et al. (2014), who indicate values between 10 and $30 \mathrm{~g} \mathrm{~kg}^{-1}$.

Regarding the sulfur (S) concentration, the single-effect analysis of the factors revealed a significant effect of the fertigation depths for both types of application (Figure 2C). For this nutrient, the maximum concentration was obtained under pulse fertigation, with an estimated value of $3.68 \mathrm{~g} \mathrm{~kg}^{-1}$ under the depth corresponding to $84.71 \%$ ETc, a $61.4 \%$ increase compared to the $40 \%$ ETc depth.

As observed for the other nutrients, whose highest concentrations were obtained with the type of application of pulse fertigation, possibly the maintenance of soil moisture caused by the splitting of irrigation throughout the day enabled the increase of S concentration in coriander cv. Verdão.

The effect of the depths considering the application of continuous fertigation led to an estimated maximum S concentration of 3.07 $\mathrm{g} \mathrm{kg}^{-1}$ under the $67 \%$ ETc depth, and the increment between this depth and $40 \%$ ETc was $7.7 \%$. Further analysis of the types of application at each fertigation depth showed a significant difference between pulse and continuous fertigation only under the $40 \%$ ETc depth (Figure 2C), with an increase of 20\% for continuous fertigation compared to pulse fertigation.

Pereira et al. (2012) obtained for this crop an S concentration of $4.5 \mathrm{~g} \mathrm{~kg}^{-1}$, a value higher than that obtained in the present study. However, the concentrations are within the range from 3 to $4 \mathrm{~g} \mathrm{~kg}^{-1}$ indicated by Trani et al. (2014). Despite the importance of this nutrient, information about mineral nutrition with $S$ in coriander plants, as well as on its relationship with irrigation techniques in the crop, is incipient in the literature.

Fe concentrations were described by quadratic equations in both types of fertigation application (Figure 3A). The highest Fe concentrations was obtained with the use of pulse fertigation, which led to an estimated maximum value of $176.5 \mathrm{mg} \mathrm{kg}^{-1}$ at the depth corresponding to $88.04 \%$ ETc, with an increase of $7.6 \%$ in comparison to the $40 \%$ ETc depth. Under the application of continuous fertigation, the maximum Fe concentration obtained was $168.99 \mathrm{mg} \mathrm{kg}^{-1}$ at the depth corresponding to $77.34 \% \mathrm{ETc}$, a $13 \%$ increment in comparison to the $40 \%$ ETc depth (Figure 3A).

According to the single-effect analysis of the type of fertigation application considering each depths (Figure 3A), there was a significant difference for Fe concentrations between 

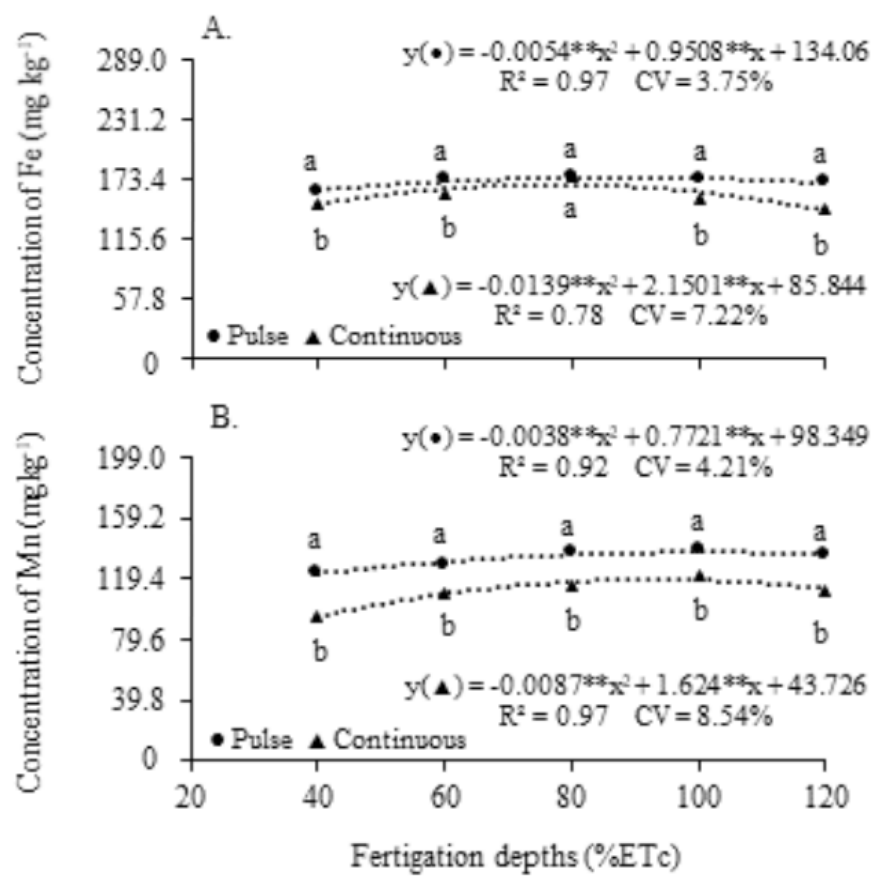

** - Significant at $\mathrm{p} \leq 0.01$ by $\mathrm{F}$ test; Equal letters on the mean values indicate non significant differences between the types of fertigation application (pulse and continuous) by the Scott-Knott test $(\mathrm{p} \leq 0.05)$

Figure 3. Concentrations of iron (Fe) (A) and manganese (Mn) (B) in coriander cv. Verdão subjected to fertigation depths and types of application

pulse and continuous fertigation under the depths of 40,60, 100 and $120 \%$ ETc, with increments of 9.3, 4.2, 8.2 and 18.6\%, respectively, for pulse application.

According to Cavalcanti et al. (2008), the adequate $\mathrm{Fe}$ concentration range for lettuce is between 100 and $500 \mathrm{mg} \mathrm{kg}^{-1}$.

A.
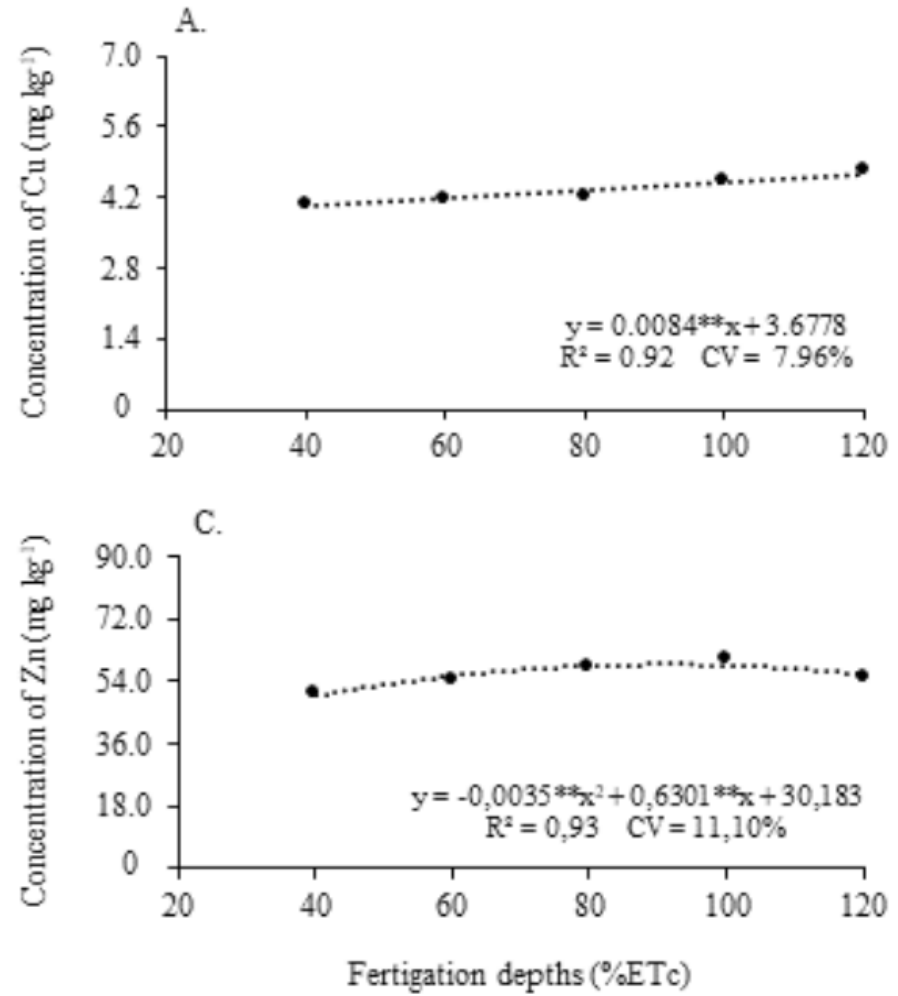

Thus, since coriander is a leafy vegetable like lettuce and there are no data regarding Fe concentrations considered adequate for the crop, the Fe concentrations obtained in this study were considered to be within the adequate range.

For both types of fertigation application, there was a quadratic effect of irrigation depths. The maximum Mn concentration estimated with the application of pulse fertigation was $137.57 \mathrm{mg} \mathrm{kg}^{-1}$ under the depth corresponding to $101.6 \%$ ETc (Figure 3B), leading to an increase of $11.7 \%$ compared to the lowest depth evaluated (40\% ETc). The application of continuous fertigation promoted an estimated maximum $\mathrm{Mn}$ concentration of $119.51 \mathrm{mg} \mathrm{kg}^{-1}$ at the depth corresponding to 93.33\% ETc, which represents an increase of $26.1 \%$ compared to the $40 \%$ ETc depth.

For the single-effect analysis of the type of application considering each fertigation depth, a significant difference was observed between pulse and continuous fertigation at all applied depths, with increments of $30,19.3,15.1,15.5$ and $20 \%$ for the depths of 40, 60, 80100 and 120\% ETc, respectively, compared to the application of continuous fertigation (Figure $3 \mathrm{~B}$ ).

Evaluating nutritional variables also in leafy vegetables, Becari (2015) verified in the arugula crop that the highest Mn concentration was obtained with the application of a depth corresponding to $60 \%$ ETc. According to Cavalcanti et al. (2008), the adequate $\mathrm{Mn}$ concentration range for lettuce crop is from 30 to $200 \mathrm{mg} \mathrm{kg}^{-1}$. Thus, as there are no data of $\mathrm{Mn}$ concentration for coriander, the Mn concentrations obtained in this study are within those indicated for lettuce.

The effects of fertigation depths and types of application on the concentrations of $\mathrm{Cu}$ and $\mathrm{Zn}$ are expressed in Figures $4 \mathrm{~A}, \mathrm{~B}, \mathrm{C}$ and $\mathrm{D}$, respectively.
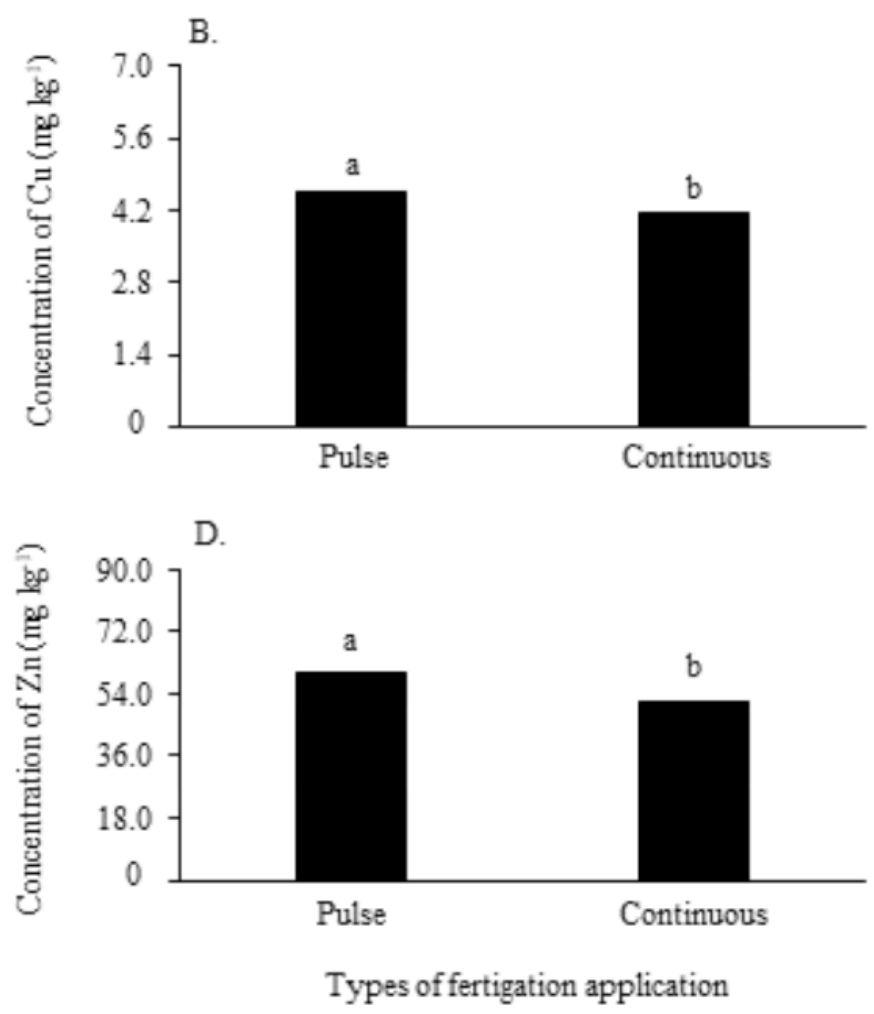

** - Significant at $\mathrm{p} \leq 0.01$ by F test; Equal letters on the mean values indicate non-significant differences between the types of fertigation application (pulse and continuous) by the Scott-Knott test $(\mathrm{p} \leq 0.05)$

Figure 4. Copper $(\mathrm{Cu})$ and zinc $(\mathrm{Zn})$ concentrations in coriander cv. Verdão as a function of the depths (A and C) and types of fertigation application (B and D) 
For the concentration of copper $(\mathrm{Cu})$, an increasing linear model was fitted (Figure 4A), with estimated average concentrations of 4.0 and $4.69 \mathrm{mg} \mathrm{kg}^{-1}$ for the depths of 40 and $120 \%$ ETc, respectively. Regarding the effect of the types of fertigation application, Figure $4 \mathrm{~B}$ shows that the highest leaf concentration of this nutrient, equal to $4.54 \mathrm{mg} \mathrm{kg}^{-1}$, occurred under the application of pulse fertigation, with an increase of $8.6 \%$ in comparison to continuous application.

It is observed that depths close to or greater than $100 \%$ ETc favor the increase of $\mathrm{Cu}$ and $\mathrm{Mn}$ concentrations in coriander cv. Verdão. Carvalho et al. (2014), studying the accumulation of nutrients in bean grains, observed that $\mathrm{Cu}$ and $\mathrm{Mn}$ concentrations were reduced with the application of depths below 100\% ETc. According to Jucoski et al. (2016), high concentrations of metal ions such as Fe can interfere in the absorption of $\mathrm{Cu}$, because they compete for the same systems of absorption and transport of nutrients in plants.

The $\mathrm{Cu}$ concentrations obtained in this study are below the adequate range for coriander indicated by Trani et al. (2014), who recommend concentrations between 8 and $15 \mathrm{mg} \mathrm{kg}^{-1}$. However, no symptoms of nutrient deficiency were observed throughout the crop cycle.

For leaf zinc $(\mathrm{Zn})$ concentrations, the data were described by a quadratic model (Figure $4 \mathrm{C}$ ), and its maximum concentration (58.54 $\mathrm{mg} \mathrm{kg}^{-1}$ ) was estimated under the application of the fertigation depth corresponding to $90 \%$ ETc, an increase of $17.6 \%$ in comparison to the fertigation depth of $40 \%$ ETc.

Regarding the effect of the types of fertigation application, Figure 4D shows that the application of pulse fertigation was the one that promoted the highest $\mathrm{Zn}$ concentration $(59.8 \mathrm{mg}$ $\left.\mathrm{kg}^{-1}\right)$, representing an increment of $15.9 \%$ in comparison to the content (51.6 mg kg-1) obtained with continuous application.

Becari (2015) found reduction in $\mathrm{Zn}$ concentration in arugula crop as a function of the increase in the amount of water applied. Trani et al. (2014) indicate concentrations between 40 and $80 \mathrm{mg} \mathrm{kg}^{-1}$ for coriander, and the concentration obtained in the present study was considered adequate for the crop.

\section{Conclusions}

1. The highest leaf concentrations of P, S and Fe were obtained in coriander cv. Verdão under application of pulse fertigation combined with ETc replacement depths lower than $100 \%$.

2. Continuous fertigation combined with $100 \%$ ETc replacement depth induces sulfur deficiency in plants and, when combined with the $40 \%$ ETc depth, promoted the highest Ca concentration in the crop.

3. ETc replacement depths from 82.7 and from $40 \%$, regardless of the type of fertigation application, promote leaf concentrations of nitrogen and magnesium, respectively, that are considered adequate for the crop.

4. Regardless of the applied depth, pulse fertigation reduced the leaf concentrations of magnesium.

\section{Literature Cited}

Albuquerque, F. S.; Silva, E. F. F.; Bezerra Neto E.; Souza E. R. A.; Santos, A. N. Nutrientes minerais em pimentão fertirrigado sob lâminas de irrigação e doses de potássio. Horticultura Brasileira, v.30, p.681-687, 2012. https://doi.org/10.1590/S010205362012000400019
Almeida, W. F. de; Lima, L. A.; Pereira, G. M. Drip pulses and soil mulching effect on american crisphead lettuce yield. Engenharia Agrícola, v.35, p.1009-1018, 2015. https://doi.org/10.1590/18094430-Eng.Agric.v35n6p1009-1018/2015

Almeida, W. F. de; Paz, V. P. da S.; Jesus, A. P. C. de; Silva, J. S. da; Gonçalves, K. S.; Oliveira, A. S. de. Yield of green beans subjected to continuous and pulse drip irrigation with saline water. Revista Brasileira de Engenharia Agrícola e Ambiental, v.22, p.476-481, 2018. https://doi.org/10.1590/1807-1929/agriambi. v22n7p 476-481

Alvares, C. A.; Stape, J. L.; Sentelhas, P. C.; Gonçalves J. L. de M.; Sparovek, G. Köppen's climate classification map for Brazil. Meteorologische Zeitschrift, v.22, p.711-728, 2014. https://doi. org/10.1127/0941-2948/2013/0507

Assouline, S.; Moller, M.; Cohen, S.; Ben-Hur, M.; Grava, A.; Narkis, K.; Silber, A. Soil-plant system response to pulsed drip irrigation and salinity: Bell pepper - Case study. Soil Science Society of America Journal, v.70, p.1556-1568, 2006. https://doi.org/10.2136/ sssaj2005.0365

Becari, G. R. G. Eficiência do uso da água e parâmetros nutricionais na cultura da rúcula submetida a diferentes condições de estresse hídrico. Botucatu: UNESP, 2015. 103p. Tese Doutorado.

Bezerra Neto, E.; Barreto, L. P. Análises químicas e bioquímicas em plantas. 1.ed. Recife: Editora Universitária da UFRPE, 2011. 267p.

Bhat, S.; Kaushal, P.; Kaur, M.; Sharma, H. K. Coriander (Coriandrum sativum L.): Processing, nutritional and functional aspects. African Journal of Plant Science, v.8, p.25-33, 2014. https://doi. org/10.5897/AJPS2013.1118

Carvalho, J. J. de; Bastos, A. V. S.; Saad, J. C. C.; Naves, S. S.; Soares, F. A. L.; Vidal, V. M. Teor e acúmulo de nutrientes em grãos de feijão comum em semeadura direta, sob déficit hídrico. Irriga, v.especial, p.104-117, 2014. https://doi.org/10.12702/ii.inovagri.2014-a138

Cavalcanti, F. L. A.; Santos, J. C. P.; Pereira, J. R.; Leite, J. P.; Silva, M. C. L.; Freire, F. J.; Silva, D. J.; Sousa, A. R.; Messias, A. S.; Faria, C. M. B.; Burgos, N.; Lima Júnior, M. A.; Gomes, R. V.; Cavalcanti, A. C.; Lima, J. F. V. F. Recomendações de adubação para o estado de Pernambuco: $2^{\mathrm{a}}$ aproximação. 3.ed. Recife: Instituto Agronômico de Pernambuco, 2008. 212p.

Daflon, D. S. G.; Freitas, M. S. M.; Carvalho, A. J. C.; Monnerat, P. H.; Prins, C. L. Sintomas visuais de deficiência de macronutrientes e boro em coentro. Horticultura Brasileira, v.32, p.28-34, 2014. https://doi.org/10.1590/S0102-05362014000100005

Elnesr, M. N.; Alazba, A. A.; Zein El-Abedein, A. I.; El-Adl, M. M. Evaluating the effect of three water management techniques on tomato crop. Plos One, v.10, p.1-17, 2015. https://doi.org/10.1371/ journal.pone.0129796

Ferreira, D. F. Sisvar: A computer statistical analysis system. Ciência e Agrotecnologia, v.35, p.1039-1042, 2011. https://doi.org/10.1590/ S1413-70542011000600001

Furlani, P. R. Instruções para o cultivo de hortaliças de folhas pela técnica de Hidroponia NFT. 1.ed. Campinas: Instituto Agronômico de Campinas, 1998. 30p.

García-Prats, A.; Guillem-Picó, S. Adaptation of pressurized irrigation networks to new strategies of irrigation management: Energy implications of low discharge and pulsed irrigation. Agricultural Water Management, v.169, p.52-60, 2016. https:// doi.org/10.1016/j.agwat.2016.02.023 
Grangeiro, L. C.; Freitas, F. C. L. de; Negreiros, M. Z. de; Marrocos, S. de T. P.; Lucena, R. R. M. de; Oliveira, R. A. de. Crescimento e acúmulo de nutrientes em coentro e rúcula. Revista Brasileira de Ciências Agrárias, v.6, p.11-16, 2011.https://doi.org/10.5039/agraria.v6ila634

Jucoski, G. de O.; Cambraia, J.; Ribeiro, C.; Oliveira, J. A. de. Excesso de ferro sobre o crescimento e a composição mineral em Eugenia uniflora L. Revista Ciência Agronômica, v.47, p.720-728, 2016. https://doi.org/10.5935/1806-6690.20160086

Lima, G. S.; Broetto, F.; Sousa, A. de P.; Correia, J. de S.; Silva, A. O. da. Impactos nutricionais e produção de pimentão submetido à deficiência hídrica. Irriga, v.21, p.724-735, 2016. https://doi. org/10.15809/irriga.2016v21n4p724-735

Oliveira, F. de A. de; Souza Neta, M. L. de; Oliveira, M. K. T. de; Silva, R. T. da; Martins, D. C.; Costa, J. P. B. de M. Production of coriander in substrate fertigated with increasing nutrient concentrations. Revista de Ciências Agrárias, v.59, p.275-279, 2016. https://doi.org/10.4322/rca.2241
Oliveira, G. M. de; Silva, M. W. da; Daamen, M. N.; Cavalcante, E. C. dos S.; Leitão, M. M. V. B. R. Evapotranspiração da cultura da cebola. Revista Verde de Agroecologia e Desenvolvimento Sustentável, v. 10, p.58-63, 2015. https://doi.org/10.18378/rvads. v10i4.3437

Pereira, M. F. S.; Linhares, P. C. F.; Macarajá, P. B.; Lima, G. K. L. de; Madeiros, G. S. Composição nutricional de cultivares de coentro por ocasião do teste de emergência de plântulas. Revista Verde de Agroecologia e Desenvolvimento Sustentável, v.7, p.1-5, 2012.

Silva, F. C. da. Manual de análises químicas de solos, plantas e fertilizantes. 2.ed. Brasília: Embrapa Informação Tecnológica, 2009. 627p.

Trani, P. E.; Purquerio, L. F. V.; Figueiredo, G. B.; Tivelli, S. W.; Blat, S. F. Calagem e adubação da alface, almeirão, agrião-d'água, chicória, coentro, espinafre e rúcula. Campinas: IAC, 2014, 16p. Informações Tecnológicas, 97. 